\title{
Analysis of Bird Diversity for Supporting Ecotourism Development in Rajegwesi, Meru Betiri National Park
}

\author{
Hafid Zain Muttaqien ${ }^{1 *}$, Luchman Hakim², Amin Setyo Leksono ${ }^{2}$ \\ ${ }^{1}$ Master Program of Biology, Faculty of Mathematics and Natural Sciences, University of Brawijaya, Malang, Indonesia \\ ${ }^{2}$ Department of Biology, Faculty of Mathematics and Natural Sciences, University of Brawijaya, Malang, Indonesia
}

\begin{abstract}
Potential ecotourism attraction in Rajegwesi Village, Meru Betiri National Park is high due to its high biodiversity, especially bird diversity, in the form of bird watching activity. This study was aimed to determine the species, level of abundance, and diversity of birds found in the Rajegwesi area. Further, this basic information is important to develop the bird watching track at Rajegwesi. We used Quantum-GIS to create the land classification and observation mapping. Bird observation used point count method in the morning and evening with three periods of hour and three repetitions. The study confirmed about 76 species of 39 bird families was found in Rajegwesi. The highest abundance was Pygnonotus goiavier (E:Yellow-vented Bulbul), at the meadows, village, and rehabilitation land. The diversity index showed that the highest diversity was found at the heterogeneous forest ( $H^{\prime}$ index 3.745), followed by homogenous forest $\left(H^{\prime}\right.$ index 3.150), rehabilitation land $\left(H^{\prime}\right.$ index 2.845), village $\left(H^{\prime}\right.$ index 2.693), paddy fields $\left(H^{\prime}\right.$ index 2.529), and savanna $\left(H^{\prime}\right.$ index 1.880). The observation track was divided into 3 lines based on the bird's distribution, the Village Rehabilitation Land track $(6.5 \mathrm{Km})$, Village track $(2.3 \mathrm{Km})$, and Village - Rafflessia Park track $(7.5 \mathrm{Km})$. Total of 25 bird species were found at the Village - Rehabilitation Land track, 22 species were found at the Village track, and 29 bird species were found at the Village - Rafflessia Park track. For the future of ecotourism development through birding development program, there are several issues that should be promoted: promoting birds conservation in the community through bird watching and birds observation competition (Bird race), training on conservation and ecotourism for the community, and strengthening the capacity and capability of Rajegwesi Ecotourism Society (RES) on the ecotourism program management.
\end{abstract}

Keywords: bird watching, conservation, ecotourism development, RES

\section{INTRODUCTION}

Bird watching are one of the ecotourism activities that rapidly growing in Indonesia. As tourism activities, bird watching has both positive and negative impact $[1,2]$. It is encourage the research activities in planning and management model of ecotourism -particularly bird watching activities- is necessary [3,4]. Mekonnen and Aticho [5] suggested that bird watching is an activity that should be encouraged in conservation because it has an important role as a source of income for local communities and promoting environmental conservation.

One spot of conservation activities attraction with high biodiversity in East Java is the Rajegwesi area, which include in Meru Betiri National Park (MB NP). As bird watching becomes popular and well developed in Indonesia, Rajegwesi (represent by Rajegwesi Ecotourism Society-RES) is also encouraged to develop their attraction of bird diversity.

\footnotetext{
* Correspondence address:

Hafid Zain Muttaqien

Email : zainrhizo@gmail.com

Address : Master Program of Biology, University of Brawijaya, Veteran Malang 65145
}

However, there are vast agroforestry developments in the area, which affect the activities of MB NP conservation.

Social aspects have been identified important in the development of bird watching activity in national park. It is encompasses the assessment of the existed bird species, area topology as the birds' habitat, and appropriate land use for the establishment of bird watching activity. Bird watching attraction as part of ecotourism was expected to build the conservation awareness [6] and further reduce the impact of agroforestry activities [7] by the local community of Rajegwesi area [8].

The aims of this study were to determine the birds' species, the level of abundance and the diversity of birds found in the Rajegwesi area. The information will be used as the consideration of bird watching track mapping in developing the strategy of ecotourism in Rajegwesi.

\section{MATERIALS AND METHODS}

The study was conducted in May to August 2012 in Rajegwesi, Meru Betiri National Park (MB NP)-Banyuwangi, East Java. The study area includes residential areas, fields, rice fields, beaches, estuaries and wilderness zone. The 
analysis was conducted at the Laboratory of Ecology and Laboratory of Bio-computing in Department of Biology, University of Brawijaya.

\section{Land Classification Map}

Land classification maps used in the study was taken from the Indonesian Earth map from Bakosurtanal for Sarongan Area in scale of 1 : 25,000 . The digitization of maps was conducted using Quantum-GIS software. Map classification based on the landscape condition. The study area including; a) heterogeneous forest area of 73.39 ha; b) homogeneous forest area of 26.49 ha planted with Sengon, Teak and coffee; c) rehabilitation area of MB NP and Perhutani used for agricultural activities by local community for $76.46 \mathrm{ha}$;) the village area for 18.84 ha; e) rice field area for 16.52 ha which is used by community around the village; and f) savanna area that is located on the waterfront, commonly used for herding buffalos by the community for 5.16 ha. The observation points were chosen within observation as seen in the map (Fig.1).

\section{Observation Spots}

Observation used point count method [9] to calculate the relative abundance, as follows. Observations were conducted in the morning and in the evening. Observation divided into three (3) periods, first hour, second hour and third hour. Morning observation is starting at 5:00 - 8:00 pm, while the evening observation starting at 15:00 18:00 pm. Observations in accordance with such procedures performed in each unit area (observation spots), with three replications.

\section{Observation on the bird watching tracks}

In this stage, researchers observed by following bird watching tracks. Based on the previous observations, there are three main tracks: the track trough the Village, the track trough VillageForest Rehabilitation, and the track trough Village-Rafflesia Park. The tracks were determined based on the packet tourist planning for future bird watching activities. The condition of the track and traveling time also considered to determine the track observations [10].

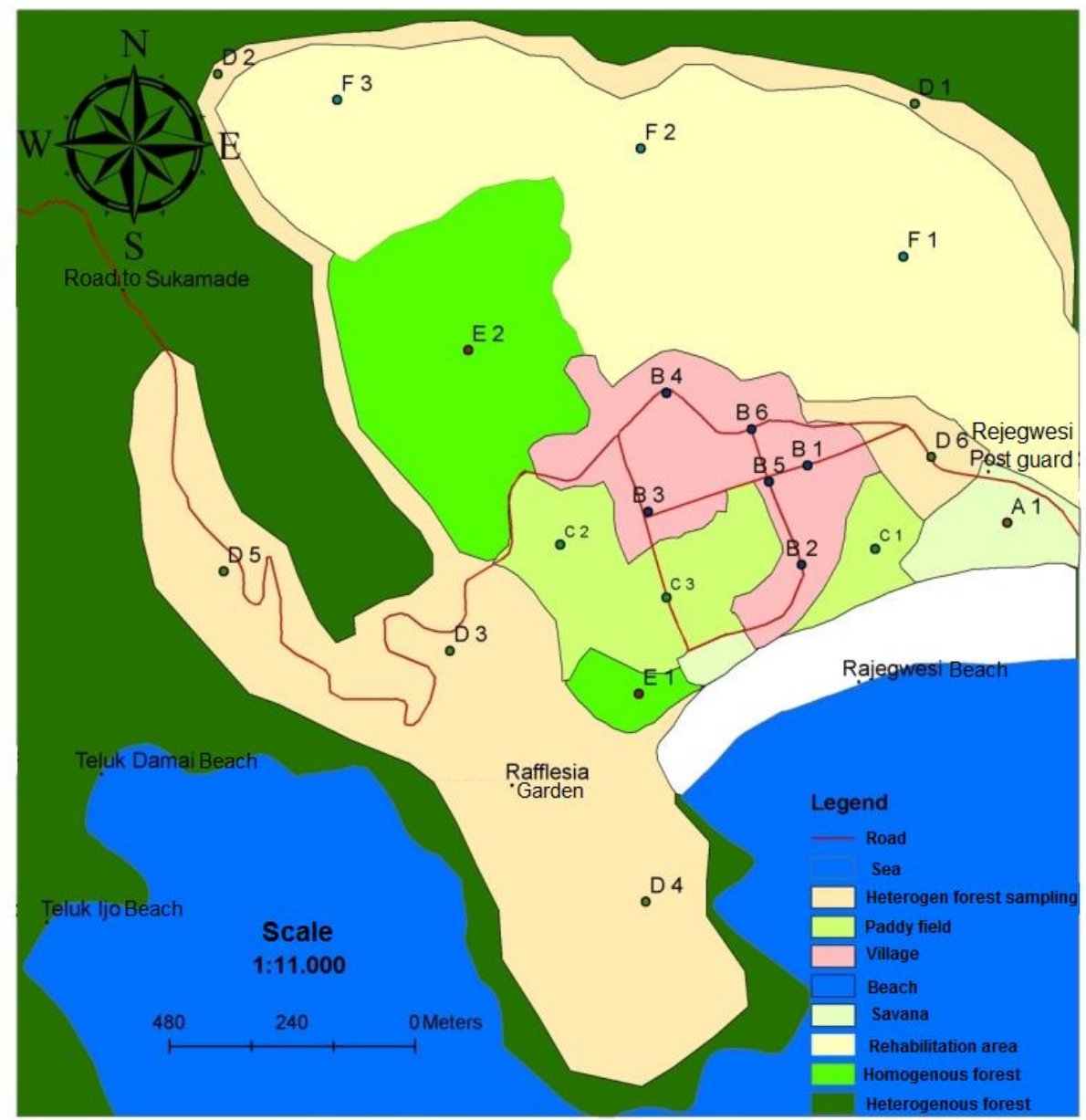

Figure 1. The map of observation area: taken and modified from the Office of Geospatial Information [11] 


\section{Data Analysis \\ Bird Diversity}

Birds' diversity on each observation area was analyzed by the index of Shannon-Wiener $\left(\mathrm{H}^{\prime}\right)$ with following formula [12]:

$$
\begin{gathered}
\mathrm{H}^{\prime}=\sum_{\mathrm{i}=1}^{s}\left(\mathrm{p}_{\mathrm{i}}\right)\left(\ln \mathrm{p}_{\mathrm{i}}\right) \\
p_{\mathrm{i}}=\frac{n_{\mathrm{i}}}{N}
\end{gathered}
$$

Description:

$\mathrm{H}^{\prime} \quad$ = Diversity index of Shannon-Wiener

$\mathrm{s}=$ number of species

$\mathrm{Pi}=$ Proportion of species no. $i$ toward total number

ni $=$ number of individu species no. $n$

$\mathrm{N}=$ total number of individu

Value of $H^{\prime}$ range are $[13,14]$ :

$<1 \quad$ : low diversity

2-3 : : medium diversity

$>3$ : high diversity

\section{Bird Species Similarity}

Species similarity was analyzed by Bray Kurtis index [13]. This index shows the species composition difference of the bird on compared community in the form of dendogram graph. The formula for the species similarity index is:

$$
\mathrm{IS}_{\mathrm{J}}=\frac{\mathrm{a}}{\mathrm{a}+\mathrm{b}+\mathrm{c}}
$$

Description:

$a$ = number of species found in both location

$\mathrm{b}=$ number of species found in location 1

$c=$ number of species found in location 2

\section{RESULT AND DISCUSSION}

Bird species

Total of 76 bird species were found and belong to 39 Families. Those species includes 20 protected species, which were two species of the Alcedinidae, two species of the Bucerotidae, two species of the Falconidae, four species of the Nectariniidae, four species of Pandionidae, and each one species of Ardeidae, Campephagidae, Oriolidae, Pittidae and Rhipiduridae.

Based on the IUCN's risk status and BirdLife International [15], there is one species of the family Pandionidae with Endangered status, i.e. Spizaetus bartelsi (Java Eagles), and four species by status Near Threatened (NT), i.e. Collocalia vulcanorum (mountain Swallow) belong to the family Apodidae, Megalaima haemacephala (Takur Ungkut-ungkut) belong to Capitonidae, Oriolus xanthonotus (forest Kepudang) belong to Oriolidae and Loriculus pusillus (Java Serindit) belong to Psittacidae [16]. The distribution of the birds found during the study presented in Table 1.

Table 1. Distribution of the birds at the observation area

\begin{tabular}{lcc}
\hline \multicolumn{1}{c}{ Area } & $\boldsymbol{\Sigma}$ Family & $\boldsymbol{\Sigma}$ Species \\
\hline Heterogeneous Forest & 34 & 68 \\
Homogenous forest & 25 & 44 \\
Rehabilitation area & 27 & 40 \\
Village & 15 & 22 \\
Rice field & 15 & 20 \\
Savanna & 9 & 10 \\
\hline
\end{tabular}

\section{Abundance and diversity of the birds}

Based on the observation area (heterogeneous forest, homogeneous forest, rehabilitation, village, rice fields and savanna), the analysis showed that the highest species diversity is heterogeneous forests (Fig. 2). Highest diversity in the forest was caused by the complexity of heterogeneous vegetation in the heterogeneous forest, which had 72 species of trees. In accordance with the statement of Wong [17] and Anderson et al. [18] that plant diversity is also an important factor to the diversity of bird species. It is also supported by Barlow [19] who mentioned that the diversity of bird species is highly correlated with basal area and the opening level of forest canopy. Areas with a large basal area and dense canopy have a greater diversity of bird species.

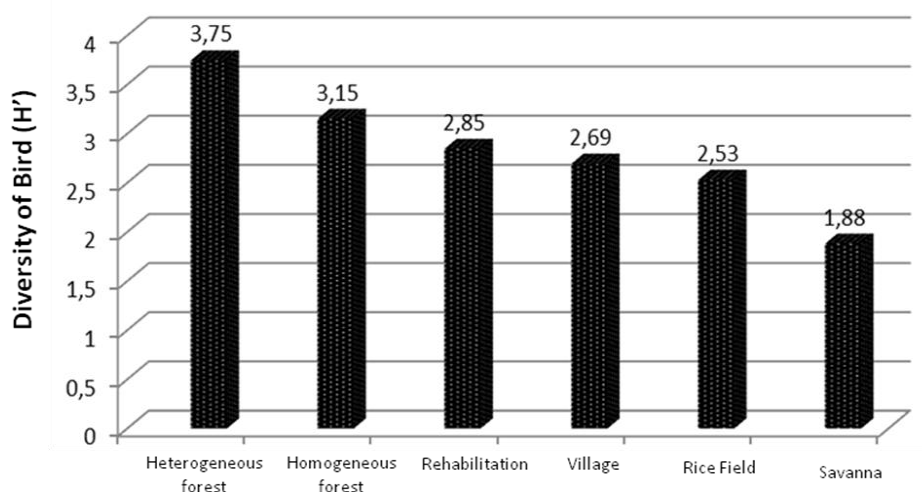

Figure 2. Diversity index of the birds at the observation area 
The same result was also obtained by Raman [20] from his research on bird communities in India. Keast $[21,22]$ wrote that a high diversity of bird species in tropical jungle was caused by tropical climate conditions which are relatively stable and friendly which allows the ecological niches and species packing being formed, diverse habitats that provided by the structure of the vegetation, the high diversity of plants, various types of food is available and the high number of rare bird species and specialists bird species.

\section{Species Similarity}

The analysis of the similarity index of bird species in each area using the Bray-Curtis index showed four (4) groups, with over $45 \%$ similarity level (Fig. 3). The first group is the birds in the rice fields, the pastures, and the village (similarity reaches $47.87 \%$ ), the second group is homogenous forests, the third group is rehabilitation land and the fourth group is heterogeneous forest.

The similarity of number and types of the birds that were found in the rice fields, pastures and villages were higher than the others (47.87\%). The similarity level was caused by several factors. First the intensity of human activity in the three areas was similar. Some birds are not too disturbed by the high human activity, such as Eurasian Tree Sparrow (Passer montanus), Yellow-vented Bulbul (Pycnonotus goiavier), Sooty-headed Bulbul (Pycnonotus aurigaster), weaver bird (Ploceus manyar), Spotted-Dove (Streptopelia chinensis), and Scalybreasted Munia (Lonchura punctulata). Those bird species are quite adaptive to the high intensity of human activity [23].
The second factor is the type of the plants in all three areas. A further factor is the guild. The guild is a group of birds that feeding on the same type of food resources and having the same habitat [24]. Change of the landscape types in Rajegwesi leads to the changes of the specific resources that affect the populations of the birds. Sixth bird species that found in all three areas were in group in feeding and nesting. These kinds of birds used the similar resources for food and nesting.

The second group is the Rehabilitation area. Rehabilitation area was initially a heterogeneous forest, but due to the changing on its landscape by agricultural activity, the composition and the abundance of bird were changed. The existence of crops that grown by the people live nearby and the presence of some forest plants made the bird species in this area were quite different [25]. The condition in rehabilitation area was different than the homogeneous forest area and heterogeneous forest area. The different types of trees in the three areas (the homogeneous forest, heterogeneous forest and the rehabilitation area) caused the differences on bird species that inhabit on the area $[26,27]$. Those three areas also have different landscape, that makes the distribution of bird is quite varied $[25,28]$.

This condition was mentioned before by Adhikerana that the distribution of birds in an area was closely related to the types of habitat $[29,30]$. The change in the landscape was a result of the human management that always had consequences on the composition and the abundance of the birds types [31,32].

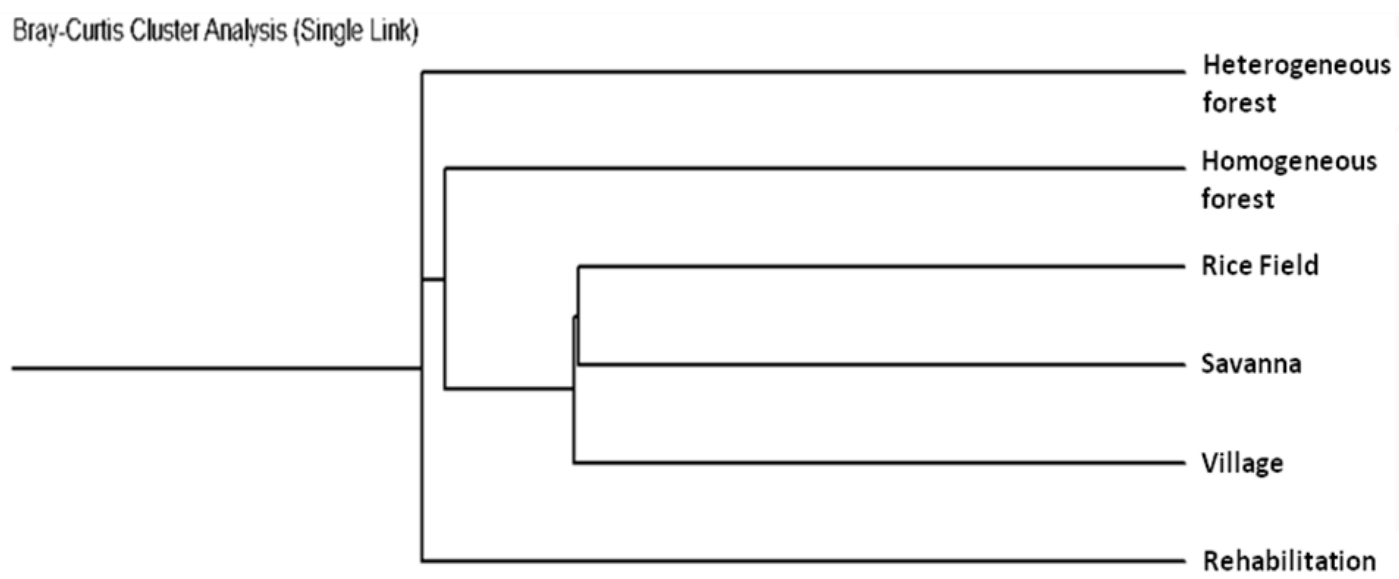

Figure 3. Dendogram of Bray-Curtis similarity index for the birds at Rajegwesi 


\section{Conclusion}

High diversity of birds' species in Rajegwesi show potential attraction to be developed for ecotourism; besides other natural attraction such as beach and forest. Development strategy of ecotourism activity, especially bird watching, is in the form of bird watching race) or group bird watching, as well as training on conservation and ecotourism for the community.

\section{Acknowledgements}

The author would like to thank the Office of Meru Betiri National Park for the research permit to collect the data in the research area.

\section{REFERENCES}

[1] Jones, D. 2010. Practices, needs and attitudes of bird-watching tourists in Australia. CRC for Sustainable Tourism. Australia, Gold Coast, Queensland.

[2] Sodhi, N. S. (Ed). 2011. Conservation of tropical birds. Blackwell Publishing. USA.

[3] Boo, E. 1990. Ecotourism, potential and pitfalls Vol. I and II. World Wildlife Fund. Washington DC.

[4] Cater, E., and Lowman. 1994. Ecotourism, a sustainable option? John Wiley \& Sons Ltd. New York.

[5] Mekonnen, T., and A. Aticho 2011. The driving forces of Boye Wetland degradation and its bird species composition, Jimma, Southwestern Ethiopia. Journal of Ecology and the Natural Environment 3(11), 365-369.

[6] Agrusa, J. F. and J. Guidry. 1999. Ecotourism and sustainable development of the Maya Rain Forest in Central America. First Pan-American Conference Proceedings 1, 34-37.

[7] Ceballos-Lascurain, H. 1996. Tourism, ecotourism and protected areas. IUCN The World Conservation Union. Gland, Switzerland.

[8] Hakim, L. 2004. Dasar-dasar Ekowisata. Bayumedia Publisher. Malang.

[9] Main, and Hostetler. 2002. Florida monitoring program: point count method to survey birds. University of Florida, Extension Institute of Food and Agricultural Science.

[10] Purvis, A., and A. Hector. 2000. Getting the measure of biodiversity. Nature 405, 212-219.

[11] BIG. 2011. Map of Sarongan Area. Office of Geospatial Information. Sarongan.
[12] Krebs, C. J. 1999. Ecological methodology, 2nd Ed. Addison-Wesley Educational Publishers, Inc New York: Harper \& Row.

[13] Leksono, A. S. 2007. Ekologi: pendekatan deskriptif dan kuantitatif. Bayumedia Publishing. Malang.

[14] Dharmawan, A. (Ed). 2005. Ekologi hewan. UM Press. Malang.

[15] BirdLife International. 2001. Threatened birds of Asia: the BirdLife International Red Data Book. Cambridge.

[16] LIPI. 2006. List of Indonesian bird No. 2. Indonesian Scientific Institute.

[17] Wong, M. 1986. Tropic organization of understory birds in a Malaysian Dipterocarp forest. Auk 103, 100-116.

[18] Anderson, B. W., R. D. Ohmart, J. Rice. 1983. Avian and vegetation community structure and their seasonal relationships in the Lower Colorado River Valley. Condor 85, 392-405.

[19] Barlow. 2007. The value of primary, secondary and plantation forests for Amazonian birds. Journal of Applied Ecology 44, 1001-1012.

[20] Raman, 2006. Consequences of rural biomass extraction for bird communities in an Indian Tropical Dry Forest and the role of vegetation structure. Conservation and Society, 562-591.

[21] Keast, A. 1985. Australia's forest and woodland avifauna: an ecological and evolutionary perspective. In: Keast, A., H. f. Recher, H. Ford, and D. Saunders (Eds). Birds of Eucalypt Forests and Woodlands: Ecology, Conservation, Management. Surrey Beatty. Chipping Norton, 11-15.

[22] Keast, A. 1985. Bird community structure in southern forests and northern woodlands: a comparison. In: Keast, A., $\mathrm{H}$. f. Recher, H. Ford, and D. Saunders (Eds). Birds of Eucalypt Forests and Woodlands: Ecology, Conservation, Management. Surrey Beatty. Chipping Norton, 97-116.

[23] Spellerberg. 2002. Ecological effects of roads. Science Publishers In c. Plymouth, United Kingdom.

[24] Connel, T. J., E. J. Laura, P. B. Robert. 2000. Bird guild as indicator of ecological condition in the central Appalachians. Ecological Application 10, 1706-1721.

[25] Bishop, J. A., and W. L. Myers. 2005. Associations between avian functional guild response and regional landscape 
properties for conservation planning. Ecological Indicators 5, 33-48.

[26] Keast, A. 1990. Australian eucalypt forest birs communities, features and adaptations. In: Keast, A. (Ed). Biogeography and Ecology of Forest Bird Communities. SPB Academic Publishing. The Hague, 285-297.

[27] Johnsingh, A. J. T., and J. Joshua. 1994. Avifauna in three vegetation types on Mundanthurai Plateu, South India. Tropical Ecology 10, 323-335.

[28] Keast, A. 1981. The evolutionary biogeography of Australian birds. In: Keast, A. (Ed). Ecological Biogeography of Australia. Dr W. Junk. The Hague, 15851635.

[29] Adhikerana, A. S. 1997. Status Burung Paruh Bangkok di Pulau Buton. Laporan Teknik Proyek Litbang dan Pendayagunaan Biota Darat Tahun 1996/1997]. Puslitbang Biologi-LIPI. Bogor.

[30] Canterbury, G. E., E. M. Thomas, R. P. Daniel, L. J. Petit, and F. B. David. 2000. Bird communities and habitat as ecological indicators of forest condition in regional monitoring. Conservation Biology 14, 544558.

[31] Van Balen, S. 1999. Birds on fragmented islands: persistence in the forests of Java and Bali. PhD thesis. Wageningen University and Research Centre, The Netherlands.

[32] Collins, S. L. 2001. Longterm research and the dynamics of birds populations and communities. Auk 118, 583-588. 